\title{
IMPROVEMENT OF ORGANIZATIONAL CULTURE: A CASE STUDY OF LITHUANIAN EDUCATIONAL INSTITUTION
}

\author{
Algirdas Giedraitis ${ }^{1}$, AUdronĖ IsPiryan ${ }^{2}$ \\ Klaipèda University (Lithuania)
}

\begin{abstract}
This article provides a synthesis of various scholarly opinions on how to improve organizational culture of the school. The qualitative research methodology was chosen for empirical research. The survey was conducted by interviewing respondents from an educational institution in Lithuania. The semi-structured interview method was applied to the study. The results showed that the factors having influence on the success and effectiveness of organizational culture and its improvement are: strong relationship between parents and the community, a student-centred learning environment, consistent institutional guidance systems, norms, values and working environment practices. In order to improve organizational culture of the educational institution, it is necessary to improve the communication and cooperation system, develop open management that would guide the community members to be responsible for their actions, to create the atmosphere involving all community members in self-learning providing feedback, promote leadership, initiate changes. The educational institution uses these determinants to create a learning organization.
\end{abstract}

KEYWORDS: organizational culture improvement, educational institution.

JEL CODES: M-14.

DOI:

\section{Introduction}

Today, the effectiveness of the school is related to the culture of the school which especially depends on organizational culture. The Lithuanian education system has experienced a huge number of structural changes but has not yet found the face of its education system. The problem is the ongoing reform which is more confusing than solving real issues. The present achievements of Lithuanian students, in comparison with other countries, clearly show poor results.

Improvement of organizational culture becomes one of the most important tools and solutions in response to emerging organizational problems (Gomez, Marcoulodes, 2012). It should be regarded as a key and priority factor for the development of the organisation. Therefore, it is appropriate to examine the links between the determinants of organizational culture that ensure the school's progress and success, and youth abilities to make changes to organizational culture. Organizational culture very strongly influences motivation and openness of teachers, students and even their parents, their ways of thinking and communicating, their emotional relationships and attitude (Kwong, Davis, 2003). The significant study seeks to show effective tools for school leaders and managers, teachers how to enable educational institution to learn and develop, gain real

\footnotetext{
Algirdas Giedraitis - associate professor (social sciences), Department of Management, Faculty of Social Sciences and Humanities, Klaipeda University

Scientific interests: management of organizations, human resources, development of organizations, management solutions

E-mail: giedraitis.algirdas@gmail.com

2 Audronė Ispiryan - Master of Educational Sciences, Šiauliai University

Scientific interests: science and business collaboration solutions, management solutions

E-mail: audrone.ispiryan@yahoo.fr
} 
competencies and apply in practice. This will create preconditions for strengthening organizational culture of the school.

Improvement of organizational culture would encourage participants in the education system to adopt fair and long-term goals oriented towards the educational system. Institution managers should link employees within these groups so that they understand each other despite different values, beliefs and norms (Knights, Willmott, 2007). Successfully developed systems and improvement of organizational culture ensure sustainability and effectiveness in developing cooperation between different stakeholders (Vveinhardt, Andriukaitiene, 2017). According to Lithuanian Audit Report (2017), the problem is, that school heads and educators are irresponsible and not accountable for the results of students' education. Therefore, this situation needs to be changed.

Organizational changes and their management are becoming an integral part of the modern world (Šimanskiené, Videikiené, 2008). Organizations are among the key units of society. During their establishment and development, a specific kind of organizational culture eventually appears. The purpose of organizational culture is to improve solidarity and cohesion, and to stimulate employees' enthusiasm and creativity to improve the organization efficiency (Tiania, 2015). Organizational culture is an issue of escalating importance if we take in consideration the structural changes of organizations which are downsizing, merging and restructuring and also the increasing complexity and unpredictability of the fast changing external environment. Understanding, assessing and managing organizational culture can help the organizations to achieve both stability and adaptability (Tanase, 2015).

The scientific problem. Factors of organizational culture at educational institutions, their potential for improvement and their usefulness to the organization are not sufficiently investigated.

The object of research. Improvement of organizational culture at the Lithuanian educational institution.

The aim of research. By identifying components and enforcement factors of organizational culture in the theoretical aspect, provide opportunities for improving organizational culture in the educational institution.

The methods of research: analysis, comparison and generalization of scientific literature; qualitative study - semi-structured interviews; interpretation of research results, data systematization.

\section{Concepts of organizational culture and issues of significance}

There are many terms used by different researchers to denote organizational culture (Ismael, 2010). The first step in building organizational culture is to define it. According to L. Šimanskienè and T. Tarasevičius (2008), "organizational culture" is an artificial culture organized for someone's special purposes. Organizational culture is evident as affecting change and constituting management content. Various Lithuanian and foreign authors have analysed organizational culture and there are various concepts of organizational culture that defines it:

- Organizational culture can be found in shared relationships among colleagues, norms within the school environment, student and teacher relations, and sharing experiences (Haberman, 2013). Organizational culture in school provides a sense of identity, promotes achievement orientation, helps shape standards and patterns of behaviour, creates distinct ways of doing things, and determines direction.

- Besner and Odiakaose (2018) give an operational definition of culture which suggests that culture comprises of three categories of beliefs: beliefs about how employees should be treated, and the opportunities afforded them; beliefs about professionalism and support of efforts to do a good job; beliefs about how the organisation interfaces with the environment and strives to accomplish its mission.

- Cultural management includes planning, processing, monitoring, and controlling of management functions in an international and cross-cultural context. Cultural management addresses the minimization of cultural conflicts for an increased organizational efficiency considering manifestations of corporate and country culture (InfoSci-Dictionary).

- Overall management culture improves the organization, simplifies and reduces the cost of management processes, determines the accuracy and consistency of work, increases labour discipline. Management culture is a key factor in the overall culture of the organization, acting directly on the organization's performance (Tanasia, Besner and Tianya, 2015). 
- T. J. Watson (2006) emphasises that the concept of culture originally derived from a metaphor of the organisation as 'something cultivated'.

- H. Odiakaose (2018) says, that „the ways an organisation operates vis a vis, its beliefs, values and assumptions is what I have conceptualized as organizational culture".

- According to M. Zeyada (2018) management culture, as a complex area of human activities, holds a special place in the today's world. When organising and managing groups of people, when achieving the goals set, managers purposefully direct the efforts of these groups. Managerial activities are the total activities of corporate management, and not only organization of activities and work of people working for this organization.

Lithuanian and foreign sociologists and managers still use different terms to define organizational culture: organizational culture, management culture; corporate culture. Organizational culture is a deliberate culture created by management, which must be very distinctive, distinguished from other similar cultures. As a connecting link, it combines the efforts of all employees to achieve common goals of the organization, based on common human, emotional, and cultural values (Šimanskienè, 2002). Organizational culture highlights its importance for maintaining the organization's internal identity and its adaptation in the environment. The study of organizational culture of the school is especially relevant, as this organisation has a special place in society, it affects the dissemination of public knowledge. Organizational culture can be seen in general categories that reflect the core values, desirable behaviour, leadership, and criteria for successful performance.

All definitions are somehow similar, and their differences arise from the fact that the authors emphasize different things. Improvement of organizational culture has assumed importance today because of the significance of the attitudes and behaviours of the members at school. A strong organizational culture provides school community members with a clear understanding of the methods and functions of an educational institution. The functions of organizational culture in the school must be oriented towards performance. It emphasizes the significance of students' opportunities offered by the school, its progress, the quality and success of the school's activities.

\section{Factors related to improvement of organizational culture}

T. J. Watson (2006) emphasises that an important trend in managerial thinking in recent decades has been one of encouraging managers trying to create strong organizational cultures. Here it is also necessary to think about provisions, perceptions, commands, leadership, motivation, organization structure, etc. It is impossible to think of these concepts, organizational cultural development without change. The quality of an educational organization's culture must be an instrument of management and development of an organization.

The whole organizational culture process needs to be done in a certain way: to identify the current organizational culture, to set the goal, to plan management decisions, to implement them, to monitor the changes, to re-examine the organization's culture, to change plans and, if necessary, to enhance change. Therefore, in order to promote organizational cultural development and positive management activities, the first step is to analyse the current culture. Even if the organisation is quite pleased with its organizational culture, evaluation is still important in order to be able to communicate in terms of current culture, work, and the direction of the future. Typical is finding the difference between the existing and the desired culture, so diagnosis is critical in order to effectively implement a space that supports the desired culture and helps to create an ideal working environment.

Organizational culture must start with measuring and understanding the current culture of an educational institution. It should be noted that in the implementation of the organization's cultural change the main role is the leader. Educational institutions' managers and leaders cannot improve culture overnight. It takes patience, sacrifice and vision. It requires that leaders have the passion to improve school and to motivate, engage, and inspire community members with more than simply words. Improving strong organizational culture takes time and commitment, but this is arguably the most important aspect. Institutions' managers and leaders should assess if organizational culture is working so that you know how to direct your management efforts. One way to 
do this is to establish what is important to educational institution and gather the community members' feedback around those elements. A significant benefit of active organizational culture is that employees see that you care. They see that culture is not static, that they have input, and that if they are unhappy with a certain aspect, they have the power to help effect positive change (Besner, 2015). To strengthen organizational culture, managers and leaders must make it a source of competitive advantages for the organization (Zeyada, 2018).

Here it is important to note that "Recommendations for the use of self-assessment tools for schools" (2016) contain the wording of school culture is a set of norms, values, loyalties, provisions, rituals and ceremonies, symbols and stories describing the school, and which is the standard for the expected school community the behavior of members. Such unwritten expectations (for example, about good teaching methods, teachers' desire to develop and develop their competences, etc.) are created over time by the common problems of teachers, administration, parents, students, jointly solved problems and barriers and challenges that are being solved simultaneously.

After analysing the organizational components of culture, it was determined that four components are especially important: strong parent-community ties, student centred learning climate, coherent institutional guidance system and norms, values and practices of the work environment. Meaningful components of organizational culture are presented in Table 1.

Table 1. Components of organizational culture

\begin{tabular}{|l|l|l|}
\hline $\begin{array}{c}\text { Components of } \\
\text { organizational culture }\end{array}$ & \multicolumn{1}{|c|}{ Actions for realization } & \multicolumn{1}{|c|}{ Authors } \\
\hline $\begin{array}{l}\text { 1. Strong parent- } \\
\text { community ties }\end{array}$ & $\begin{array}{l}\text { The quality of these ties links directly to students'motivation and school } \\
\text { participation and can provide a critical resource for classrooms,offer } \\
\text { or the opportunity to work together; encourage communication in } \\
\text { person, explain decisions that are made and demonstrate respect, } \\
\text { sincerity, consideration and empathy; communicate the decisions of } \\
\text { the management to the teachers and parents and solicit their opinion }\end{array}$ & $\begin{array}{l}\text { M. Haberman } \\
\text { (2013); }\end{array}$ \\
(2002); D. Clark \\
(2009)
\end{tabular}


According to the data in Table 1, none of the above four organizational cultural components separately reveals its substance. But all together, they can form organizational culture. Organizational culture creates a sense of order, continuity, and commitment that permeates every aspect of the organization. Organizational culture is an organization's reality, it shows what's going on in the organization. It is often difficult for an organization to articulate the improvement of organizational culture, but its impact is far reaching and influences management, process, students' results, reputation, and ultimately the bottom line. Organizational culture is a tool for achieving the desired activity results.

\section{Research methodology and results}

The aim of identifying the organizational culture components and enforcement factors in the theoretical aspect, provide opportunities for improving organizational culture in an educational institution.

The study was carried out at Kelme district school. Educational programs run in the school are: the second part of the basic education program, secondary education, non-formal education. The school employs 55 teachers and has 400 students.

The qualitative research started from the collection of qualitative data, followed by their analysis by the chosen content analysis method. As organisations ultimately consist of individuals, it is futile to contemplate management of organisations without giving due consideration to their human aspects such as emotions, moods, relationships and well-being (Härtel, 2008). The research was based on finding the meanings that would be based on interesting views, evaluations and opinions, seeking to comprehend and describe the subject in detail, therefore, the research results were based on different data sources and semi-structured interviews with managers and teachers working at school.

The questionnaire was prepared based on scientific and literature analysis. Anonymous questionnaires were provided to experts. The questionnaire contains questions and possible answers. The choice of research instrument was determined by the desire to get as diverse, new and original information as possible. Pre-defined topics and issues were discussed during the interviews but not strictly attributed to them. During the interviews, the questions were replaced by places requested, in order to obtain more detailed, important data, and a variety of responses that can be examined. The aim was to identify the organizational culture components and enforcement factors, opportunities for improving organizational culture in the analysed educational institution. One secondary school was selected in order to answer the established research questions: What encourages the development of the school's organizational culture? Why? What factors have the greatest impact on the positive changes in organizational culture at school? (school style, school strategy, school community relationships, school values, school structure, school's internal environment, school rules, requirements, school behaviour, etc.)? Why do you think so? Please, justify; What do you think should be changed so that to improve the organizational culture of the school? Why? What else would you like to say about the subject under the discussion?

During the interviews, six experts were aimed at finding out what problems are encountered seeking to improve organizational culture and which factors determine their application. There were selected respondents that met all the criteria indicated in Table 2.

Table 2. Information about experts

\begin{tabular}{|l|l|l|l|l|}
\hline Codes & Age & Position & Education & Work experience \\
\hline IN001 & 56 and more & manager & Master's degree & 31 year \\
\hline IN002 & 46-55 years & deputy & Master's degree & 26 year \\
\hline IN003 & $46-55$ years & deputy & Master's degree & 21 year \\
\hline IN004 & 36-45 years & teacher & Bachelor's degree & 14 year \\
\hline IN005 & 46-55 years & teacher & Bachelor's degree & 18 year \\
\hline IN006 & $36-45$ years & teacher & Master's degree & 15 year \\
\hline
\end{tabular}


Experts were asked to select and mark only one the most relevant statement, even if both appeared to be acceptable. The respondents were also asked to choose the answer that best suited their personal experience, not how they would like it to be.

The findings of the study, selected and grouped opinions, provision that specify the components of cultural welfare and the actions of its realization are presented in Table 3.

Table 3. The findings of qualitative research

\begin{tabular}{|c|c|}
\hline $\begin{array}{l}\text { Components of } \\
\text { organizational culture }\end{array}$ & Actions for realization \\
\hline $\begin{array}{l}\text { 1. Strong parent- } \\
\text { community ties }\end{array}$ & $\begin{array}{l}\text { Enabling management (25), influencing others ( } 7) \text {, knowledge of the social, cultural, political } \\
\text { and economic context and appropriate behaviour (10), reasonableness of progress (18), } \\
\text { implementing and developing innovations (28), effective leadership (28), sharing information } \\
\text { and verifying ideas (12), research and self-assessment (9), conflict analysis together (5) }\end{array}$ \\
\hline $\begin{array}{l}\text { 2. Student centred } \\
\text { learning climate }\end{array}$ & $\begin{array}{l}\text { Targeting goals and results (14), communication and collaboration (26), training and } \\
\text { educating together (19), use of creative work methods (11) }\end{array}$ \\
\hline $\begin{array}{l}\text { 3. Coherent institutional } \\
\text { guidance system }\end{array}$ & $\begin{array}{l}\text { Initiating the changes (21), creating an innovative environment (7), division of } \\
\text { responsibilities (6), agreements (22), generating ideas in teams (6) }\end{array}$ \\
\hline $\begin{array}{l}\text { 4. Norms, values and } \\
\text { practices of the work } \\
\text { environment }\end{array}$ & $\begin{array}{l}\text { Motivation and individual values (15), leader's responsibility for provision and values } \\
\text { (8), effectiveness, creativity, creating and developing success factors, values (29), skills } \\
\text { as respect for the opinion of others, honesty, responsibility (12) }\end{array}$ \\
\hline
\end{tabular}

After examining the components of organizational culture (Table 3), it was found out that the organization's effectiveness depends on its members' ability to work together to achieve a common goal, and on the organization's coordinated functions, which should be coordinated based on well-defined and consistent relationships. The analysis revealed that this institution must take into account: improvement effectiveness, creativity, creation and development of success factors, values (29 statements related to the action), implementation and development of innovations ( 28 statements related to the action), effective leadership ( 28 statements related to the action), organizational culture enabling management ( 25 statements related to the action), agreements (22 statements related to the action), initiation of changes (21 statements related to the action). While collecting and analysing the important organisational culture components, we see that there should be an agreement, a clear distribution of responsibilities, and a system of motivation. Functions of school culture and their quality can help not only external evaluators to explore the school's culture and interpret the results, but also be of use to school communities for to identify and improve the factors that determine the school's culture. Improvement of the function of school culture can be a particularly important tool for school management.

Table 4. Solutions for improvement of organizational culture

\begin{tabular}{|c|c|}
\hline Actions & Solutions for improvement \\
\hline $\begin{array}{l}\text { Creating and developing } \\
\text { success factors, values (29) }\end{array}$ & $\begin{array}{l}\text { - A combination of formal and non-formal ideals, norms and principles creates the } \\
\text { character or spirit of a school. Its educational effect: the degree of positiveness, } \\
\text { strength, consistency } \\
\text { - Self-assessment of activities with the participation of interested parties is an } \\
\text { essential factor in improving the quality of education and an incentive to create a } \\
\text { learning, socially responsible organization }\end{array}$ \\
\hline $\begin{array}{l}\text { Communication and } \\
\text { collaboration }(26)\end{array}$ & $\begin{array}{l}\text { - Education is effective and the school community is involved in the reflection and } \\
\text { implementation of school tasks: pupils, their parents, teachers and other staff, } \\
\text { and administration. Taking into account community-based values and outcomes, } \\
\text { they assume different responsibilities and together they create the school's unique } \\
\text { environment for education (education) and communion-a model for a future society } \\
\text { - Support for change gives an emotional connection and communication } \\
\text { - Organizational culture is created on reflection and learning }\end{array}$ \\
\hline
\end{tabular}




\begin{tabular}{|c|c|}
\hline Actions & Solutions for improvement \\
\hline Enabling management (25) & $\begin{array}{l}\text { - School leaders initiate changes, their interaction with other members of the } \\
\text { community, communication and cooperation skills are especially important } \\
\text { - } \quad \text { Management is creative, open and responsible } \\
\text { - } \quad \text { Established mechanisms involve young people in identifying school needs and } \\
\text { ensure their participation in a constructive dialogue at all decision-making levels } \\
\text { - Systematic analysis made systematically based on scientific analyses } \\
\text { - } \quad \text { Developed leadership is a central position in organizational culture } \\
\text { - Managers play a key role as creators of culture underlying assumptions }\end{array}$ \\
\hline Agreements (22) & $\begin{array}{l}\text { - The time and space for communications, agreements, exchange, reflection is } \\
\text { considered as valuable and very important } \\
\text { - Community members share their vision and mission and feel motivated to help } \\
\text { achieve them following agreements } \\
\text { - Students feel that their ideas and suggestions are valued and are being followed } \\
\text { upon critical reflection. Mistakes and failures are seen as learning opportunities, } \\
\text { rather than something that has to be blamed on someone and therefore to be hidden } \\
\text { or denied. Realising agreements by communication of knowledges has meaningful } \\
\text { benefits } \\
\text { School managers take some precautions, plan their actions, realise them in according } \\
\text { with community members }\end{array}$ \\
\hline Initiating the changes (21) & $\begin{array}{l}\text { - Implement at school qualitative school self-esteem research practices, which would } \\
\text { reveal the quality of ongoing processes, create opportunities for generating new } \\
\text { ideas } \\
\text { Develop an innovation action plan for culture that includes specific measures to } \\
\text { involve as many community members as possible to improve learning, agreements, } \\
\text { standards of conduct, value enhancements (meetings for sharing good practice, } \\
\text { improving and developing information channels, discussions, reflection and etc.) } \\
\text { Create a permanent school system for promoting youth in order to increase } \\
\text { motivation for their learning, the generation and implementation of original ideas }\end{array}$ \\
\hline
\end{tabular}

Summarising Table 4 and following the experts' opinion, the presented success criteria revealed important steps for improvement of organizational culture. It is very important for the educational institution: to improve communication and cooperation skills, develop creative, open and responsible management; establish mechanisms which involve young people in identifying needs and ensure their participation in a constructive dialogue at all decision-making levels; systematically make important systematic analysis based on scientific analyses; develop leadership as a central position in organizational culture, promote leadership as it plays a key role in creating a culture underlying assumptions.

\section{Conclusions}

The analysis of scientific literature revealed the organizational components of culture, determining the four especially important components: strong parent-community ties, student centred learning climate, coherent institutional guidance system and norms, values and practices of the work environment. None of the above four organizational cultural components separately reveals its substance. But all together, they can form organizational culture in the educational institution.

The results obtained from this qualitative study (6 respondents) shows, that the educational institution must take into account changes in efficiency, creativity, creation and improvement of success factors, values and development (29 statements related to the action), innovation and development ( 28 statements related to the action), effective organizational culture-management (25 statements related to the action), effective group of leaders (28 statements related to the action), initiation for changes (21 statements related to the action). By creating and improving a shared learning organizational culture, one can cultivate the relationships that power the best future of the educational institution. When you create an environment that promotes learning it does not only help you to hire the best talents, to improve students' achievements but also keeps them in 
high positions. The essential tasks for improving organizational culture must be focused on creating opportunities, removing obstacles, encouraging growth, and providing guidance or solutions in the mentioned fields. When teachers and students feel they are engaged in meaningful work and belong to a good team led by an inspiring leader, they experience a positive teaching, learning climate. Realisation of the mentioned solutions for improvement of organizational culture offers interesting alternative approaches to change education into more desirable, simplifies and reduces educational processes, increases students' achievements. Such strong organizational culture is characterized by professionalism, commitment, honour, dignity, and faith in people.

Thus, in order to improve organizational culture, it is recommended and necessary to improve the communication and cooperation system, develop open and responsible management, create the atmosphere involving all community members in self-learning providing feedback, promote leadership, initiate changes. The educational institution uses these determinants to create a learning organization. Combination of formal and non-formal ideals, norms and principles creates the character or spirit of a school that has great educational effect: the degree of positiveness, strength, consistency. Developing of self-assessment activities with the participation of interested parties is an essential factor in improving the quality of education and an incentive to create a learning and socially responsible organization. The educational institution must involve the school community in the reflection and implementation of school tasks. Taking into account community-based values and outcomes, they assume different responsibilities and together they create the school's unique environment for education and communion - a model for the future society.

\section{References}

Ashkanasy, N. K., Wilderom, P. M., Peterson, M. F. (2000). Handbook of Organisational Culture and Climate. Sage Publications: London.

Besner, G. (2015). Why We Should be Focusing on Culture Management. Available at: https://www.entrepreneur.com/ article/248262 [Accessed: September 20, 2018].

Bryk, A. S., Sebring, P. B., Allensworth, E., Luppescu, S., Easton, J. Q. (2010). Organizing Schools for Improvement: Lessons from Chicago. Chicago: University of Chicago. Available at: https://www.qrisnetwork.org/sites/all/files/ materials/OrganizingSchools.pdf [Accessed: September 9, 2018].

Clark, D. J. (2009). The Impact of Leadership and Culture on Student Achievement: Case Study of a Successful Rural School District. Available at: https://core.ac.uk/download/pdf/62868839.pdf [Accessed: October 2, 2018].

DuBrin, A. J. (2002). Fundamentals of Organizational Behaviour. USA: Thomson Learning.

DuPlessis, Y.(2004). The DevelopmentofanAssessment Toolfor Measuring Project Management Culturein Organisations. Available at: https://repository.up.ac.za/bitstream/handle/2263/25349/Complete.pdf?sequence=10\&isAllowed=y [Accessed: September 20, 2018].

Gomez, M. O., Marcoulodes, G. A., Heck, R. H. (2012). Examining Culture and Performance at different Middle School Level Structures. International Journal of Educational Management, Vol. 26(2), p. 205-222.

Haberman, M. (2013). Why School Culture Matters, and How to Improve It. Available at: https://www.huffingtonpost. com/Michael-Haberman/why-school-culture-matter_b_3047318.html [Accessed September 5, 2018].

Härtel, C. (2008). How to Build a Healthy Emotional Culture and Avoid a Toxic Culture. Available at: https://www. researchgate.net/publication/288438687_How_to_build_a_healthy_emotional_culture_and_avoid_a _toxic_culture [Accessed: September 27, 2018].

Ismael, Y. A. (2010). A Review Paper on Organizational Culture and Organizational Performance. Available at: http:// ijbssnet.com/journals/Vol._1_No._3_December_2010/4.pdf [Accessed: January 10, 2019].

Kwong, D., Davis, J. R. (2003). School Climate for Academic Success: A Multilevel Analysis of School Climate and Student Outcomes. Available at: https://files.eric.ed.gov/fulltext/EJ1098022.pdf [Accessed: August 27, 2018].

Lietuvos Respublikos švietimo ir mokslo ministro 2016 m. kovo 29 d. ísakymas Nr. V-267 (2016). Mokyklos, igyvendinančios bendrojo ugdymo programas, veiklos kokybès isivertinimo metodika. Available at: https://www. smm.lt/uploads/documents/Pedagogams/2 Metodika.pdf [Accessed August 27, 2018].

McCollum, E. C., Yader, N. P. (2011). School Culture, Teacher Regard and Academic Aspirations among Middle School Students. Middle Grades Research Journal, Vol. 6 (2), p. 65-74.

Odiakaose, H. (2018). Organisational Culture and Dynamics. Available at: file://C:/Users/Ligita/AppData/Local/ Temp/2406-1-2388-1-10-20180305.pdf [Accessed: January 7, 2019].

Tanasia, I. A. (2015). The Importance of Organizational Culture Based on Culture Transfer. Available at: http://conferinta.management.ase.ro/archives/2015/pdf/89.pdf [Accessed: January 10, 2019]. 
Tianya, L. (2015). Organizational Culture and Employee Behavior. Available at: https://www.theseus.fi/bitstream/handle/10024/92815/LI_Tianya.pdf [Accessed Janvier 08, 2019].

Šimanskienė, L., Videikienè, S. (2008). Pokyčiu valdymo sèkmès veiksniai organizacijose. Available at: https://repository.mruni.eu/bitstream/handle/007/15120/Videikienè.pdf?sequence=1\&isAllowed=y [Accessed: January 8, 2019].

Šimanskienė, L., Tarasevičius, T. (2008). Organizacinès kultūros ir vadovu tipu sąsajos. Available at: http://vadyba.asu. 1t/20/146.pdf [Accessed: September 15, 2018].

Valstybinio veiklos audito stebésenos ataskaita Nr. VA-2017-P-50-1-20. (2017). Available at: https://www.vkontrole.lt/ audito_ataskaitos.aspx?tipas=2 [Accessed Ostober 1, 2018].

Vveinhardt, J., Andriukaitiene, R. (2017). Management Culture as Part of Organizational Culture in the Context of Corporate Social Responsibility Implementation. Available at: http://www.economics-sociology.eu/files/25_21_461_ Vveinhardt_Andriukaitiene.pdf [Accessed: August 29, 2018].

Zeyada, M. (2018). Organizational Culture and its Impact on Organizational Citizenship Behavior. Available at: http:// hrmars.com/hrmars_papers/Organizational_Culture_and_its_Impact_on_Organizational_Citizenship_Behavior. pdf [Accessed: January 8, 2019].

Watson, T. J. (2006). The Organization and Disorganization of Organization Studies. Available at: https://onlinelibrary. wiley.com/doi/abs/10.1111/j.1467-6486.2006.00594.x [Accessed: October 1, 2018].

Westhuizen, P. C., Mosoge, M. J., Swanepoel, L. H., Coetsee, L. D. (2005). Organizational Culture and Academic Achievement in Secondary Schools. Education and Urban Society, Vol. 38, p. 89-109.

\title{
ORGANIZACINÉS KULT ÜROS TOBULINIMAS : LIETUVOS ŠVIETIMO ISTAIGOS ATVEJIS
}

\author{
Algirdas Giedraitis, AUdronĖ IsPIRYAN \\ Klaipèdos universitetas (Lietuva)
}

\section{Santrauka}

Šiandien mokyklos veiksmingumas siejamas su jos kultūra, kuri ypač priklauso nuo organizacijos kultūros (OK). Lietuvos švietimo sistemoje įvyko nemažai struktūrinių pokyčių, tačiau gerai veikiančios sistemos vis dar nerasta. Problemų kyla dèl vykstančios reformos, kuri yra paini ir nesprendžia realių bėdų. Lietuvos studentų rezultatai, palyginus juos su kitų šalių aukštujjų mokyklų rezultatais, atskleidžia, kad yra gerokai prastesni. Remiantis Lietuvos valstybinio veiklos audito stebėsenos ataskaita (2017), problema ta, kad mokyklų vadovai ir pedagogai nèra atsakingi ir atskaitingi už moksleivių ugdymo rezultatus. Organizacinès kultūros tobulinimas tampa viena svarbiausių priemonių, ieškant organizacinių problemų sprendimų.

Šiame straipsnyje pateikiama organizacinès kultūros švietimo ịstaigoje sudedamụjų dalių ir vykdymo veiksnių sintezè, kultūros švietimo ịstaigos tobulinimo organizacinès galimybès ir rekomendacijos. Kurdama ir tobulindama bendrą mokymosi organizacinę kultūrą mokykla pasieks geresnių veiklos rezultatų, moksleiviai ịgyvendins užsibrěžtus tikslus. Pagrindiniai OK tobulinimo uždaviniai: galimybių sudarymas, kliūčių šalinimas, pažanga minètose OK sėkmę skaninančiose srityse, patarimų ar sprendimų teikimas.

Siekiant pagerinti švietimo ịstaigos organizacinę kultūrą, būtina tobulinti bendravimo ir bendradarbiavimo sistemą, plètoti atvirą valdymą, vadovaujant bendruomenès nariams, kad visi būtų savarankiški ir atsakingi už savo veiksmus, kurtų pozityvų ir darbingą mikroklimatą. Mokykloje būtina skatinti lyderystę, inicijuoti pokyčius. Švietimo institucija turètų igyvendinti rekomendacijas, siekdama sukurti nuolat tobulèjančią mokymosi organizaciją.

Pasirinktas kokybinis tyrimas, taikant iš dalies struktūruoto interviu metodą. Tyrimas atliktas Kelmès rajono mokykloje. Kokybinio tyrimo (6 ekspertai) rezultatai atskleidè, kad organizacinès kultūros tobulinimo sėkmingumą ir veiksmingumą veikiantys veiksniai yra: glaudus tėvų ir bendruomenės ryšys, studentų centruoto mokymosi aplinka, nuoseklios institucinès orientavimo sistemos, normos, vertybès ir darbo 
aplinkos praktika. Siekiant tobulinti švietimo įstaigos organizacinę kultūrą, būtina skatinti OK tobulinimo sėkmę garantuojančius komunikacinius veiksnius, igalinančius vadybą, susitarimą ir kaitos politiką, sèkmès veiksnius, puoselèti vertybes. Tobulinant organizacinę kultūrą siūlomos alternatyvos, kaip ịgyvendinti pageidaujamus pokyčius švietimo sistemoje, supaprastinti ir pagerinti edukacinius procesus, ịtraukti moksleivius ir juos ịgalinti siekti pageidaujamų rezultatų. Mokytojams ir mokiniams tikint, kad jie dirba ir mokosi prasmingai bei geroje komandoje, mokomasi pozityviai ir pasiekiama užsibrèžtų rezultatų.

PAGRINDINIAI ŽODŽIAI: organizacinès kultūros tobulinimas, švietimo ịstaiga.

JEL KLASIFIKACIJA: M-14. 